\title{
Let the Life go on
}

7 his column has ignited a new spark to pen down memorable moments in our day-to-day life. Practicing with rural parents is great fun. They are flooded with innocence. A child with viral diarrhea, who has been duly explained for likely recovery in 5-6 days, lands with his grandfather the very next day with a grudging appeal: "ek paise ka aaram nahin hai" (not even a penny worth of relief!). Similarly, when asked for the symptoms, the reply is a simple: "tum hi samajh lo" (you figure out yourself). When a very sick child is advised for hospitalization, his parent would ask bluntly: "kya tumhare bas me nahin hai?" (Is it beyond your capacity to treat?). In contrast, the urban internet-savvy elite, with a touch of arrogance, would ask for a complete diagnosis. They would persistently argue for feeding with a bottle, while the rural parent throws away the bottle with the first advice: "Tumne kahi hum phek de rahe" (I threw it away as you instructed).

Young children are certainly intelligent, innocent, innovative, interesting, and filled with pure thoughts. Entering into the chamber, he/she would command immediately: "Dekho injection mat lagana" (Beware! No injection). While examining for ear pain, while observing the normal ear one would say "Ismen kuch nahin hai" (Nothing wrong with this one). Sometimes, the younger one would demand his check-up after his ailing sibling, and we would have to oblige him with a beam of flashlight in the mouth, and stethoscope on the chest. Even then, he would grudge: "Array peechey to dekho" (look at the back too), step forward for taking weight, and would not sit down till a fake prescription has been handed out.
Even in the 21st century, no matter what the educational background is, the rift between dadi (paternal grandmother) and nani (maternal grandmother) is never ending. Mother while going to nani's house gets strict advise from her mother-in-law to make sure that the grandchild does fine, "dekho ja to rahe ho bachhe ka dhyan rakhna" (You are going all right, but take due care of the child). In this era of technology, she regularly communicates on mobile and wants to see the grandchild on Skype! Similarly when nani (maternal grandmother) brings her granddaughter to the clinic, she wants "jaldi se theek ho jaye raji khushi apne ghar jaye" (desperately needs her to get well soon and go back peacefully).

We are both lucky and fortunate to get into the specialty of Pediatrics, and have the privilege of interacting with agile children and their energetic caring parents. Our colleagues in other streams of medicine are often jealous of us! When a proud father - who was himself under our care while he was young - introduces his son for routine checkup, it unleashes a rush of adrenaline that sends us shivering with pride and satisfaction. Most of the tiny tots enjoy playing and fighting with their peers in the waiting hall and start screaming with our glimpse in the chamber, but in between an innocent and pleasant million dollar smile of a six-month-old infuses a new wave of joy and strength, to go on and on.

Pradeep Kumar Mehta Mehta Clinic, Ranital Chowk-Shahid Smarak Link Road, Jabalpur, MP, India. pkmehta71@gmail.com 